\title{
FATORES CONDICIONANTES DA CONFIGURAÇÃO DE FUNDOS DE VALE COLMATADOS NA BACIA DO ALTO-MÉDIO RIO POMBA, LESTE DE MINAS GERAIS
}

\author{
CONDITIONING FACTORS OF THE ALLUVIAL BOTTOM VALLEYS \\ CONFIGURATION AT THE HIGH-MIDDLE POMBA RIVER BASIN, EAST \\ OF MINAS GERAIS STATE
}

\author{
Letícia Augusta Faria de Oliveira \\ Instituto de Geociências, Universidade Federal de Minas Gerais \\ Avenida Antônio Carlos, 6.627, Pampulha, Belo Horizonte/MG, Cep: 31270-901, Brasil \\ E-mail: leticia.afoliveira@gmail.com \\ Antônio Pereira Magalhães Junior \\ Instituto de Geociências, Universidade Federal de Minas Gerais \\ Avenida Antônio Carlos, 6.627, Pampulha, Belo Horizonte/MG, Cep: 31270-901, Brasil \\ E-mail: magalhaesufmg@yahoo.com.br
}

Laura Bertolino de Souza Lima Instituto de Geociências, Universidade Federal de Minas Gerais Avenida Antônio Carlos, 6.627, Pampulha, Belo Horizonte/MG, Cep: 31270-901, Brasil E-mail: laurasouzalima@yahoo.com.br

Alex de Carvalho Instituto de Geociências, Universidade Federal de Minas Gerais Avenida Antônio Carlos, 6.627, Pampulha, Belo Horizonte/MG, Cep: 31270-901, Brasil E-mail: alexrochacarvalho@gmail.com

\section{Informações sobre o Artigo}

Data de Recebimento:

28/01/2014

Data de Aprovação:

04/11/2014

\section{Palavras-chave:}

Dinâmica fluvial quaternária;

Vales colmatados; Lumines-

cência Opticamente Estimulada (LOE).

\section{Keywords:}

Quaternary fluvial dynamics; Alluvial bottom valleys; Optically Stimulated Luminescence (OSL).

\section{Resumo:}

O estudo das formações aluviais na reconstituição de eventos geomorfológicos é uma ferramenta metodológica importante para a compreensão dos processos de esculturação dos vales fluviais, da configuração espaço-temporal da rede hidrográfica e, consequentemente, da configuração do modelado do relevo no Quaternário tardio. Este trabalho investiga hipóteses sobre os fatores condicionantes que levaram à configuração de expressivos depósitos aluviais resultantes da colmatação de fundos de vale na bacia do Alto-Médio Rio Pomba, região leste de Minas Gerais. Os fundos de vale apresentam espessos depósitos de terraço nos quais as planícies, por vezes com grandes amplitudes, encontramse embutidas ou encaixadas. O quadro geológico e geomorfológico regional, as idades obtidas para os sedimentos via técnica de Luminescência Opticamente Estimulada (LOE) e a disposição de trechos de corredeira no médio Rio Pomba sugerem que a gênese dos depósitos fluviais esteve condicionada por uma tectônica diferencial de blocos durante o Quaternário tardio. A morfologia das 
planícies se deve a fatores tectônicos e, em menor grau, também a fatores antrópicos, além de ser influenciada pela morfologia da bacia do Rio Pomba. A datação dos depósitos aluviais via LOE se mostrou útil e adequada para mensurar a idade de episódios recentes de deposição aluvial. Cinco dentre os seis depósitos de planície datados obtiveram entre $1.500( \pm 250)$ e $6.000( \pm 750)$ anos de idade, sendo as planícies de baixo curso mais velhas que as de alto curso. Nesse período, o encaixamento do canal no trecho próximo ao ponto de coleta foi nulo ou inferior a 1 m. A idade de 16.000 ( \pm 1.500$)$ anos obtida para um dos depósitos de planície do Rio São Manuel (bastante divergente, portanto, das demais) pode ter sido ocasionada pelo zeramento parcial da luminescência dos grãos de quartzo anteriormente à deposição, em decorrência da proximidade entre o local da coleta e a escarpa da Serra da Mantiqueira. Para o nível de terraço datado, foi obtida a idade de $11.800( \pm 1.000)$ anos, durante os quais houve um encaixamento de $4 \mathrm{~m}$ do curso d'água.

\begin{abstract}
:
The study of the alluvial formations on the reconstitution of geomorphological events is an important methodological tool for the comprehension of the origin of the fluvial valleys, the temporal-space configuration of the hydrographical system and, consequently, the relief configuration in the late Quaternary. Such work investigates hypotheses about conditional factors that brought to the configuration of expressive alluvial deposits resulted from the catchments aggradation in the bottom of valleys in the high-middle Rio Pomba basin, which lies in the east region of Minas Gerais. The valley bottoms present thick terrace levels in which alluvial plains, sometimes with great amplitudes, have been found nested or cut-in-bedrocks. The regional geological and geomorphological framework, the ages of alluvial sediments (obtained by Optically Stimulated Luminescence - OSL technique) and the spatial distribution of rapids at the fluvial beds of the middle Rio Pomba suggest that the genesis of fluvial deposits was conditioned by a differential block tectonics during the late Quaternary. The morphology of the plains is due to tectonic factors and, in a lower degree, also to anthropic factors, besides being influenced by the morphology of Rio Pomba basin. The dating of alluvial deposits by OLS has showed itself useful and appropriated to dating recent episodes of alluvial deposition. Five out of the six deposits of dated plain obtained were between $1.500( \pm 250)$ and $6.000( \pm$ 750) years old. The plains of low courses were older than the high courses ones. At this period, the downcutting of the channel in the distance near the collection points was null or shallower than a meter deep. The age of 16.000 $( \pm 1.500)$ years obtained for one of the deposits of the plain of the Rio São Manuel (plenty divergent, therefore, of those ones) may have been caused by the partial bleaching of the luminescence of quartz grains previously the deposition, resulting from the proximity between the local of the collection and the Serra da Mantiqueira scarp. For the dated terrace, it was obtained the age of $11.800( \pm 1.000)$ years, during those years there was a downcutting of four meters of the water course.
\end{abstract}

\section{Introdução}

A dinâmica fluvial é bastante sensível ao comportamento das variáveis geológicas e exógenas, fazendo com que, não raro, depósitos aluviais guardem registros das condições tectônicas e climáticas vigentes nos períodos sin e pós deposicionais. A adoção das formações aluviais na reconstituição de eventos geomorfológicos é, portanto, uma ferramenta metodológica importante para a compreensão dos fatores condicionantes da evolução da rede de drenagem no Quaternário tardio. Os registros aluviais também são elementos tradicionalmente empregados na reconstituição dos processos de esculturação dos vales fluviais, na compreensão da configuração espaço-temporal da rede hidrográfica e, consequentemente, na configuração do modelado do relevo.

Na Zona da Mata de Minas Gerais, a bacia do Alto-Médio Rio Pomba (afluente de margem esquerda do baixo curso do Rio Paraíba do Sul) apresenta amplos fundos de vale entulhados que podem atingir $500 \mathrm{~m}$ de largura, com expressivos níveis deposicionais recentes (terraços e planícies). Considerando-se o dinamismo tectônico da faixa atlântica brasileira durante o Cenozoico e os reflexos do evento Sul-Atlantiano na estruturação do relevo do Brasil oriental (Almeida, 1976; Summerfield, 1991; Saadi, 1993; Salvador e Riccomini, 1995; Santos, 1999; Hiruma et. al., 2001; Salamuni et. al., 2004; Hartwig e Riccomini, 2009), não é difícil 
pressupor um importante condicionamento neotectônico na dinâmica fluvial cenozoica na Zona da Mata mineira. Segundo Salvador e Riccomini (1995), no Alto Estrutural de Queluz (SP-RJ), a mudança no regime de esforços ocorrida durante o Holoceno ocasionou a formação de pacotes sedimentares de até $30 \mathrm{~m}$ de espessura.

Neste trabalho, são propostas hipóteses sobre os fatores condicionantes que levaram à configuração dos expressivos fundos de vale colmatados na bacia do AltoMédio Rio Pomba, região leste de Minas Gerais. Estes fundos de vale apresentam espessos níveis de terraços (média de $10 \mathrm{~m}$ ) nos quais as planícies, por vezes com grandes amplitudes (superiores a $500 \mathrm{~m}$ de largura), encontram-se embutidas ou encaixadas. $\mathrm{O}$ quadro geológico e geomorfológico regional, as idades obtidas via LOE para os sedimentos aluviais e a disposição de trechos de corredeira no Médio Rio Pomba e em seus afluentes auxiliaram as reflexões.

\section{Área de Estudo}

A bacia do Alto-Médio Rio Pomba, tributário do Rio Paraíba do Sul, se situa na Zona da Mata mineira, tendo como limite norte o divisor entre as bacias dos rios Doce e Paraíba do Sul (Figura 1). Abrange parte da Depressão Escalonada dos Rios Pomba e Muriaé (neste trabalho denominada Depressão do Rio Pomba), bem como a sua transição para o Planalto dos Campos das Vertentes (PROJETO RADAMBRASIL, 1983) e parte deste, e o Horst da Serra da Boa Vista (Noce et. al., 2003). Foram contemplados os vales do próprio Rio Pomba e de seis de seus afluentes: Ribeirão Espírito Santo, Rio São Manuel, Ribeirão Ubá, Rio Paraopeba, Rio Xopotó e Rio dos Bagres.

A área apresenta unidades litológicas de idades predominantemente paleoproterozoicas a neoproterozoicas, localmente recobertas por sedimentos alúvio-

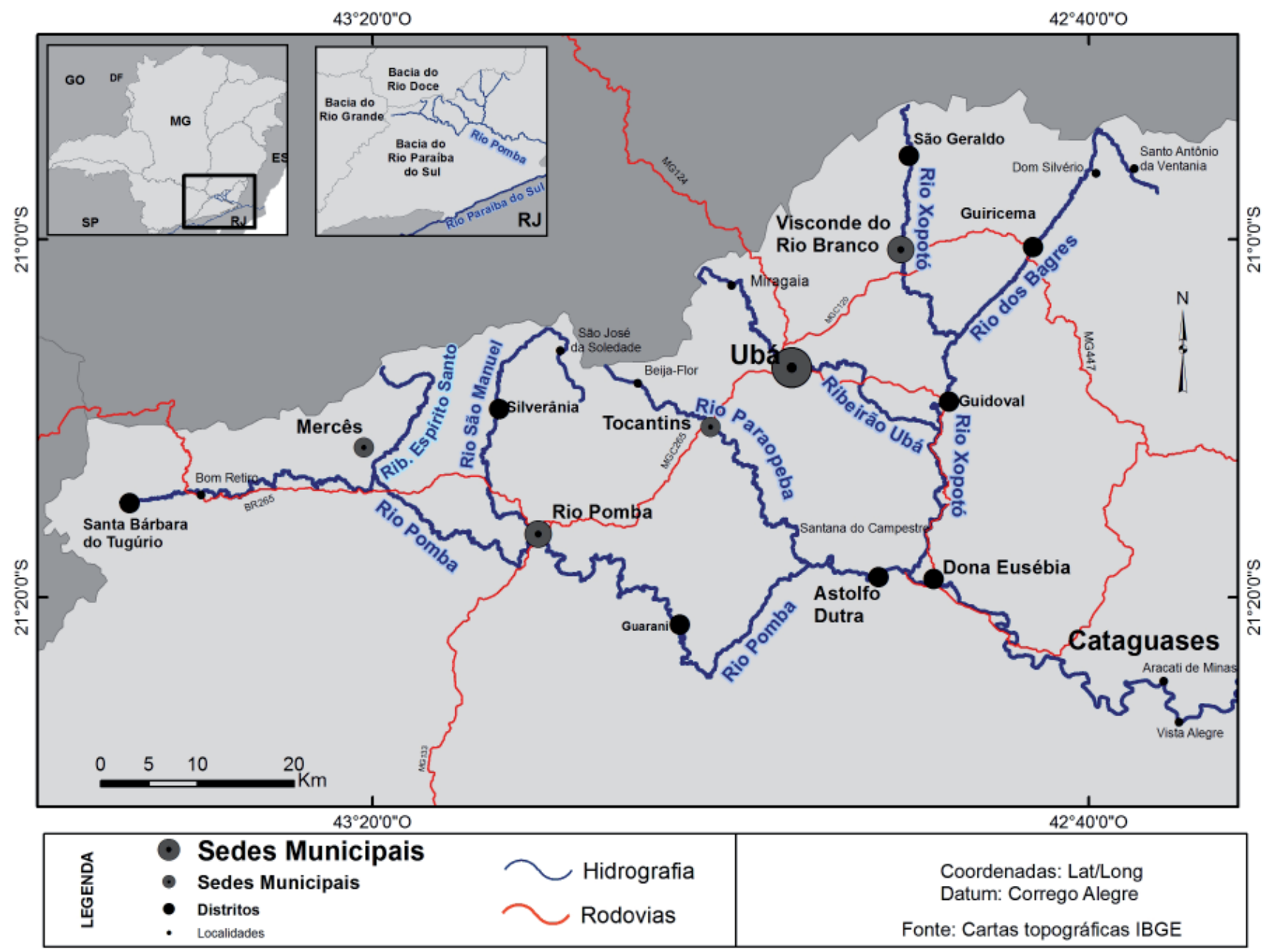

Figura 1 - Localização dos vales estudados 
coluvionares cenozoicos (Figura 2). No Complexo Mantiqueira predominam biotita-hornblenda gnaisses cinzentos, bandados, de composição tonalítica a granodiorítica. O Complexo Juiz de Fora corresponde a um complexo plutônico que engloba rochas máficas a félsicas, metamorfisadas na fácies granulito. No setor oeste da área ocorrem rochas do Complexo Mercês, principalmente metagranitos alcalinos a cálcio-alcalinos, metassienitos cálcio-alcalinos, metassienitos alcalinos e granada-biotita gnaisses. (Brandalise e Viana, 1993; Noce et. al., 2003). As principais estruturas regionais possuem direção NE-SW e idade pré-cambriana. Como reflexos das deformações, as maiores unidades litológicas tendem a orientar-se segundo faixas de direção SW-NE e, secundariamente, E-W, a exemplo da falha na qual se instala o Alto Rio Pomba.

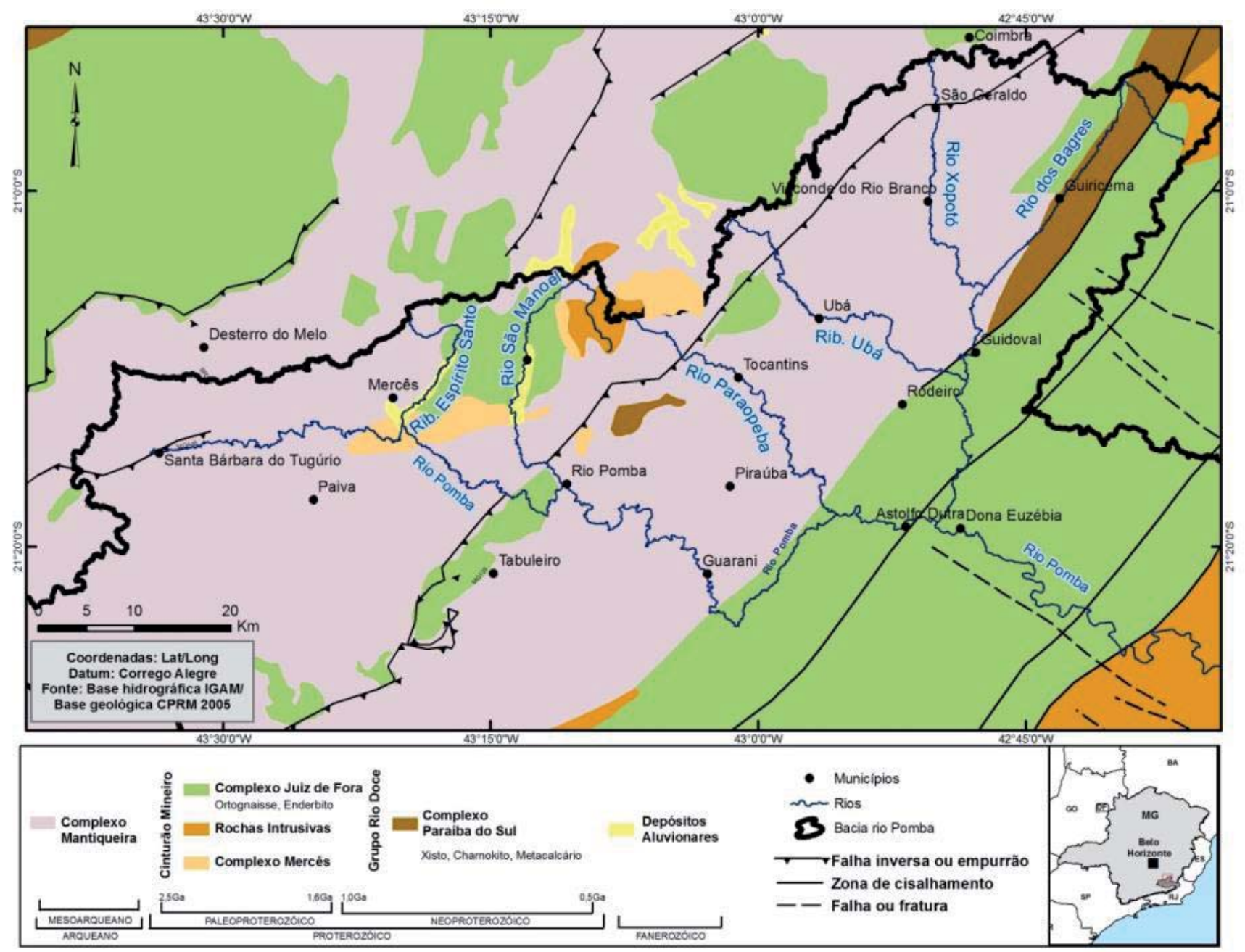

Figura 2 - Quadro geológico regional

Em termos morfológicos, a Depressão do Rio Pomba representa o setor mais rebaixado e suave da área de estudo, localizado no setor central e nordeste da mesma (Figura 3). É caracterizada por relevo colinoso, com topos convexos ou tabulares, dissecado pelos cursos d'água pertencentes à bacia do Alto Rio Pomba. Raposo e Salgado (2010) destacam a topografia suave da Depressão do Rio Pomba e ressaltam o predomínio de amplas planícies nos fundos dos vales de afluentes do canal principal. Já o Planalto de Campo das Vertentes, a noroeste da área, correspondente a área intensamente dissecada em formas mamelonares, com presença de escarpas acentuadas e vales estruturais profundos (PROJETO RADAMBRASIL, 1983). Rodrigues (2011), ao encontrar valores semelhantes de densidade de drenagem e densidade hidrográfica para bacias hidrográficas de ambos os compartimentos morfológicos mencionados, atribuiu a semelhança à similaridade litológica das 
bacias. Uma vez que não há condicionante litológico ou estrutural que delimite o contato entre as unidades geomorfológicas, o autor atribuiu à Depressão do Rio Pomba uma gênese relacionada a processos erosivos controlados pela dinâmica fluvial, que responde, por sua vez, à diferença de potencial erosivo da rede de drenagem regional, advinda dos diferentes níveis de base que a controlam. O Horst da Serra da Boa Vista tem cerca de $20 \mathrm{~km}$ de extensão e direção NE-SW (Noce et. al., 2003). Em relação ao quadro tectônico regional, Noce et. al. (2003) destacam o dinamismo tectônico do Horst da Serra da Boa Vista durante o Cenozoico. Os trabalhos de Riccomini (1989), Saadi (1993), Salvador (1994), Mello (1997), Ferrari (2001), Sarges (2002), Silva e Limeira Mello (2011) salientam a alternância do regime de esforços ao qual o Sudeste brasileiro está sujeito ao longo do Cenozoico.

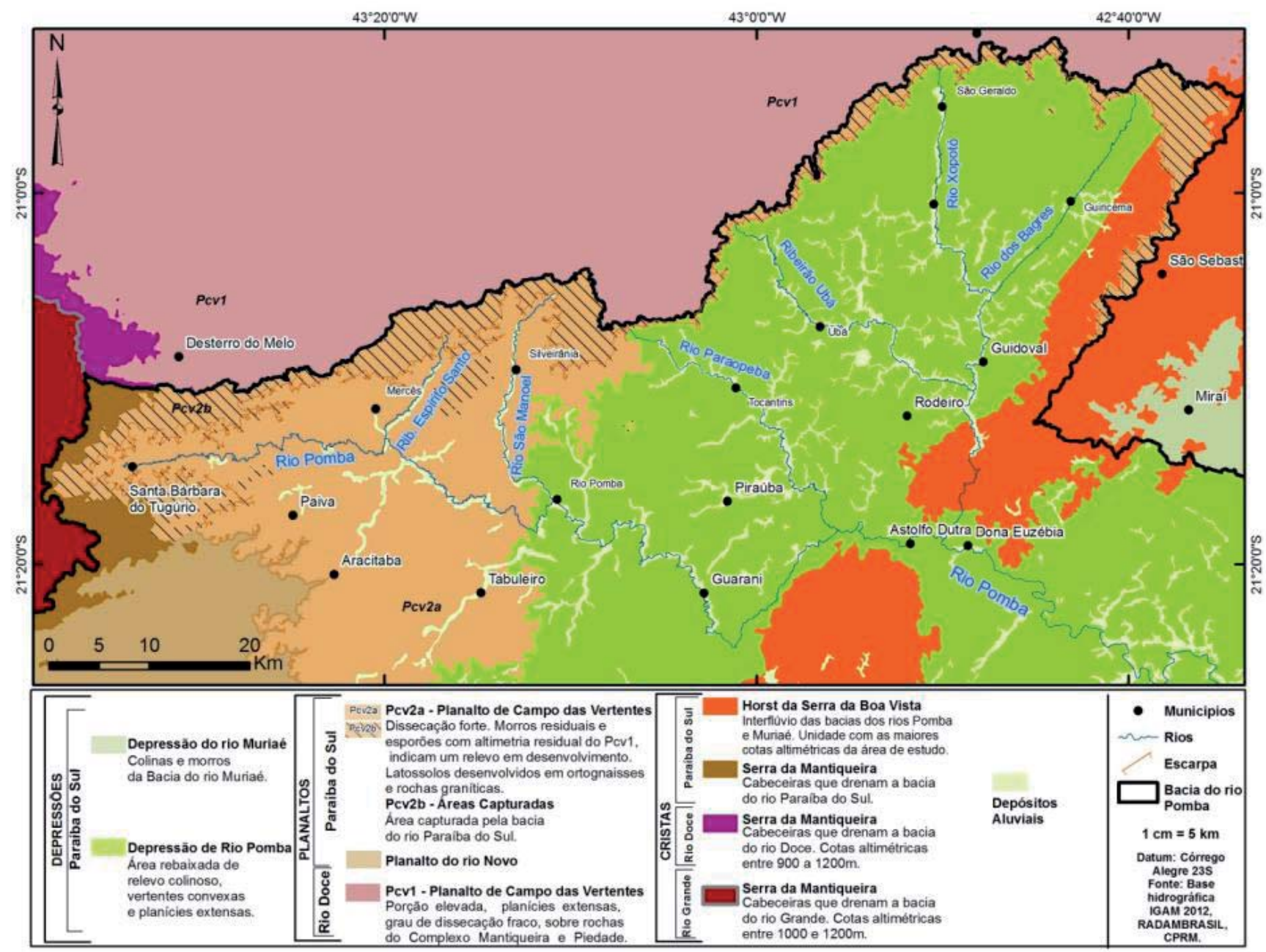

Figura 3 - Principais unidades do relevo regional

\section{Procedimentos Metodológicos}

As feições morfológicas, os aspectos geológicos e o padrão de drenagem dos vales estudados foram previamente analisados por meio de imagens de satélite de alta resolução no Google Earth $\AA$, de cartas topográficas do IBGE (Instituto Brasileiro de Geografia e Estatística) na escala 1:250.000 (folhas Ponte Nova e Juiz de Fora) e de mapas geológicos na escala 1:100.000 (folhas Ubá e Rio Pomba). Após trabalhos de campo para reconhecimento da área, foram selecionados afluentes de margem esquerda do Alto-Médio Rio Pomba que apresentam fundos de vale colmatados, com significativos níveis deposicionais aluviais e com indícios de condicionamento estrutural, sobretudo pelos grandes lineamentos brasilianos (padrão retilíneo do canal, cotovelos, rede de 
drenagem com padrão retangular). Aárea foi delimitada com o auxílio da configuração dos perfis fluviais longitudinais e da configuração dos fundos de vale.

Após as etapas de revisão bibliográfica e de definição dos vales a serem estudados, foram realizadas temporadas de campo para a identificação e caracterização dos níveis e sequências aluviais, incluindo a tipologia dos níveis, a sua posição em relação à calha atual e o contexto espacial nos vales, a textura dos sedimentos (verificada em campo por meio do tato), a presença de estruturas deposicionais, a espessura das fácies e o tipo de transição entre elas. As sequências aluviais de cada nível deposicional foram representadas em perfis estratigráficos. Feições de leito foram descritas e a sua ocorrência foi espacializada de modo que se visualize a localização das sequências de poços e corredeiras.

Para a datação absoluta dos sedimentos, foi escolhida a técnica LOE - Luminescência Opticamente Estimulada, via protocolo SAR - single aliquot regeneration (Sallun e Suguio, 2006; Sallun et. al., 2007). Esta escolha ocorreu em função desta técnica ser mais adequada à datação de grãos de quartzo, já que a fração arenosa é a textura predominante nos depósitos de interesse (Missura e Corrêa, 2007). A técnica de LOE permite a datação do último evento deposicional que expôs o sedimento à luz do dia. O sinal luminescente é armazenado no mineral durante todo o intervalo de tempo em que este se encontra ao abrigo de luz solar e em contato com as radiações ambientais. Sendo transportado em meio aquoso ou aéreo, o mineral é exposto à luz ou ao calor e o sinal de luminescência adquirido anteriormente à erosão do mineral é "zerado". Portanto, uma nova acumulação começa após a deposição do sedimento, quando este for recoberto e mantido fora do alcance da luz solar (Corrêa et. al., 2008). Como o sinal luminescente, dentro de certos limites, cresce proporcionalmente com a dose de radiação incidente e com o tempo de irradiação, é possível determinar o tempo transcorrido desde que a população aprisionada de elétrons foi liberada pela última vez (Wallinga, 2002), medindo-se em laboratório a luz emitida em resposta ao estímulo óptico fornecido (Sallun e Suguio, 2006). Desde que haja a adequada eliminação do sinal de LOE durante o transporte do sedimento, pode-se assegurar, portanto, que a idade calculada corresponde à idade do soterramento do mineral.

A leitura do sinal luminescente via LOE pode ser feita via dois protocolos: o protocolo de alíquotas múltiplas (multiple aliquot regenerative-dose-MAR) e o protocolo de alíquotas únicas (single aliquot regenerative-dose - SAR). Pelo MAR, as medições são feitas em cerca de 20 a 40 grãos minerais, nos quais são aplicadas diferentes doses de radiação e os resultados permitem delinear uma "curva de crescimento", que representa a resposta da luminescência do material à radiação (Le e Wintle' 1992 apud Sallun et. al., 2007). Pelo SAR, são feitas muitas medidas de luminescência sobre grãos individuais, o que possibilita diminuir o erro e identificar se o sinal de luminescência foi completamente zerado em todos os grãos (Sallun et. al., 2007), sendo, portanto, o protocolo que atribui maior confiabilidade e precisão aos resultados. Por estes motivos, o protocolo SAR foi adotado neste trabalho. A técnica de datação por LOE permite obter idades que variam de poucas dezenas de anos até cerca de 1,5 Ma anos (Sallun e Suguio, 2006).

A datação foi realizada no Laboratório de Vidros e Datação da Faculdade de Tecnologia de São Paulo (FATEC). Os depósitos datados foram selecionados tendo em vista a sua relevância e representatividade para as interpretações sobre a origem dos espessos pacotes sedimentares de fundos de vale, bem como a disponibilidade de material datável e as condições de coleta no depósito. Foram coletadas amostras da fração arenosa basal, visando-se obter as idades do início dos processos de entulhamento. Ademais, a parte superior dos depósitos foi mais alterada por processos erosivos e pedológicos. Para a coleta, foram utilizados amostradores de tubos de PVC com $30 \mathrm{~cm}$ de comprimento, tomando-se o cuidado da não exposição das amostras à radiação solar. Os tubos, previamente identificados e envoltos por sacos plásticos pretos, foram inseridos horizontalmente nos sedimentos por meio de percussão utilizando-se uma marreta de borracha, em conformidade com procedimentos detalhadamente descritos por Sallun et. al., (2007). As amostras foram enviadas para o Laboratório Datação, Comércio e Prestação de Serviços Ltda. (LVD - SP), onde foram preparadas e analisadas de acordo com a técnica LOE - via protocolo SAR. 


\section{Descrição dos Resultados}

\section{Níveis e sequências deposicionais de fundos de vale}

Os canais que drenam o Planalto de Campos das Vertentes (Pcv2a e Pcv2b Figura 3), a saber, Ribeirão Espírito Santo e Rio São Manuel apresentam, predominantemente, padrão meandrante. Ao longo de todo o fundo de vale, observa-se um nível de terraço (N2) escalonado em relação ao nível fluvial imediatamente mais antigo (N3). O N3 não se encontra mais em contexto de fundo de vale e sua morfologia original de terraço já foi descaracterizada por processos de vertente. O N2 tem espessura variando entre 10 e $20 \mathrm{~m}$ e, nele, amplas planícies (N1) ocorrem embutidas ou encaixadas. Nesse setor da área de estudo, os vales são abertos, de fundo plano, preenchidos predominantemente pelos depósitos de terraço e, por vezes, são observáveis trechos da calha em corredeira. Morfologia semelhante de vale e leito ocorre nos vale dos altos cursos dos Rios Xopotó e Paraopeba, e do Ribeirão Ubá, à montante dos municípios de São Geraldo, Tocantins e Ubá, respectivamente (Figura 3).

Já os cursos d'água que drenam a Depressão do Rio Pomba (Rios Xopotó e Paraopeba, e Ribeirão Ubá, Figura 3), em seus médios e baixos cursos, apresentam apenas depósitos de planície (N1), que chegam a atingir $500 \mathrm{~m}$ de largura e nos quais meandros abandonados são frequentes. Níveis deposicionais aluviais mais antigos não são encontrados. Seus vales são abertos (ainda mais abertos que os vales que drenam o Planalto de Campos das Vertentes). Quedas d'água e trechos encachoeirados no médio-baixo Rio Xopotó e no baixo Rio Paraopeba têm atuado como soleiras geomorfológicas, estabilizando o nível de base e permitindo a esses cursos d'água e ao Ribeirão Ubá intenso meandramento. O Rio dos Bagres, embora também drene a Depressão do Rio Pomba, apresenta forte controle estrutural, o que interfere em seu processo de migração lateral. Neste vale é possível observar depósitos de terraço ao longo de toda a extensão do canal, que apresenta padrão predominantemente retilíneo. Níveis deposicionais aluviais mais antigos, atualmente pertencentes a um contexto de vertente, também são encontrados ao longo de todo o vale. Trata-se de um vale mais estreito que os demais, no qual o fundo de vale, também menos desenvolvido, concede ao vale características de vale em "V".
Já nos trechos nos quais os canais cruzam o Horst da Serra da Boa Vista (Figura 3), os vales e as planícies são estreitos, não se observa níveis deposicionais abandonados e as calhas são rochosas. Embora os cursos d'água preservem seu padrão meandrante, a morfologia dos vales nesse trecho é muito diferente das que se observa à montante e à jusante do horst.

A descrição detalhada dos depósitos de N2 e dos depósitos de N1 de cada vale é apresentada na Figura 4, permitindo a comparação das características de cada um desses níveis nos diferentes vales. Por meio da figura, pode-se observar que as características faciológicas e a distribuição espacial dos níveis deposicionais de fundo de vale apresentam similaridades entre os diferentes vales investigados. Via de regra, em toda a área de estudo os terraços $(\mathrm{N} 2)$ ocorrem escalonados em relação ao nível deposicional aluvial mais antigo (N3) e não apresentam exposição do substrato rochoso no contato com as planícies (N1), a não ser nos altos cursos dos canais, onde a fácies basal das mesmas está depositada sobre substrato rochoso. Os terraços correspondem a pacotes amplos em ambas as margens do canal, espessos (espessura frequentemente superior a $10 \mathrm{~m}$ ) e formados por fácies de seixos intercaladas com fácies finas. Já as planícies apresentam pacotes de cerca de 2 a $3 \mathrm{~m}$ de espessura, compostos por fácies basal de seixos, à qual se sobrepõe fácies fina frequentemente arenosa. Uma vez que os depósitos de um mesmo nível são semelhantes entre os vales quanto à espessura do pacote e, no caso dos terraços, à alternância entre fácies grosseiras e fácies finas, foi possível elaborar um perfil síntese do nível de planície e um perfil síntese do nível de terraço, que serão detalhadamente descritos a seguir. Cabe ressaltar que cada perfil síntese expressa as características de um nível deposicional em todas as suas ocorrências e é o resultado da sobreposição das informações adquiridas com a análise de seus diversos perfis encontrados.

\section{Descrição do perfil-síntese dos depósitos de terraço (N2)}

Os terraços são lateralmente extensos e bastante recorrentes em ambas as margens dos cursos d'água. Nos altos cursos, observa-se fácies basal de seixos, de espessura variando entre 0,5 e $1 \mathrm{~m}$, composta predominantemente por seixos de quartzo e esparsos seixos de granito, arredondados a subangulosos, mal selecio- 
nados, com comprimento médio de $5 \mathrm{~cm}$, suportados entre si. Comumente, entretanto, trata-se de um depósito formado por intercalações de camadas arenosas, com ou sem a presença de grânulos e pequenos seixos, com camadas areno-argilosas, ou argilo-arenosas. Cada camada tem, em média, entre 1 e $2 \mathrm{~m}$ de espessura. Seixos de quartzo ou rochas ígneas máficas, arredondados a subangulosos, ocorrem esparsos em fácies arenosa comumente estratificada (estratificação planar) (Figura 5). Os depósitos têm, em média, $10 \mathrm{~m}$ de espessura e tornam-se mais espessos nos médios e baixos vales do Ribeirão Espírito Santo e do Rio São Manuel, canais que drenam o Planalto de Campos das Vertentes (Pcv2a e Pcv2b Figura 3). Este nível também ocorre nos altos cursos dos vales dos Rios Paraopeba e Xopotó, e do Ribeirão Ubá, bem como ao longo de todo o vale do Rio dos Bagres, os quais drenam a Depressão do Rio Pomba (Figura 3).
Descrição do perfil-síntese dos depósitos de planície (N1)

Em todos os vales, as planícies ocorrem embutidas ou encaixadas no nível de terraço (geralmente não há a exposição dos contatos) e apresentam fácies basal de cerca de $50 \mathrm{~cm}$ de espessura, composta por seixos e grânulos subarredondados a angulosos (comprimento médio de $3 \mathrm{~cm}$ ), predominantemente de quartzo e rochas ígneas máficas, suportados por matriz arenosa maciça. O limite superior do nível de seixos encontra-se a cerca de $50 \mathrm{~cm}$ da lâmina d'água, enquanto a base frequentemente não pode ser visualizada. A fácies superior das planícies é arenosa, com estruturas planares e espessura média $3 \mathrm{~m}$ (Figura 5). As planícies são lateralmente amplas, sobretudo nos baixos cursos dos canais que drenam a Depressão do Rio Pomba, onde alcançam até $500 \mathrm{~m}$ de extensão. Conforme já mencionado, nessas porções dos vales, os amplos depósitos de planície correspondem a todo o fundo de vale, não sendo observados os espessos depósitos de terraço nem quaisquer outros níveis fluviais abandonados.

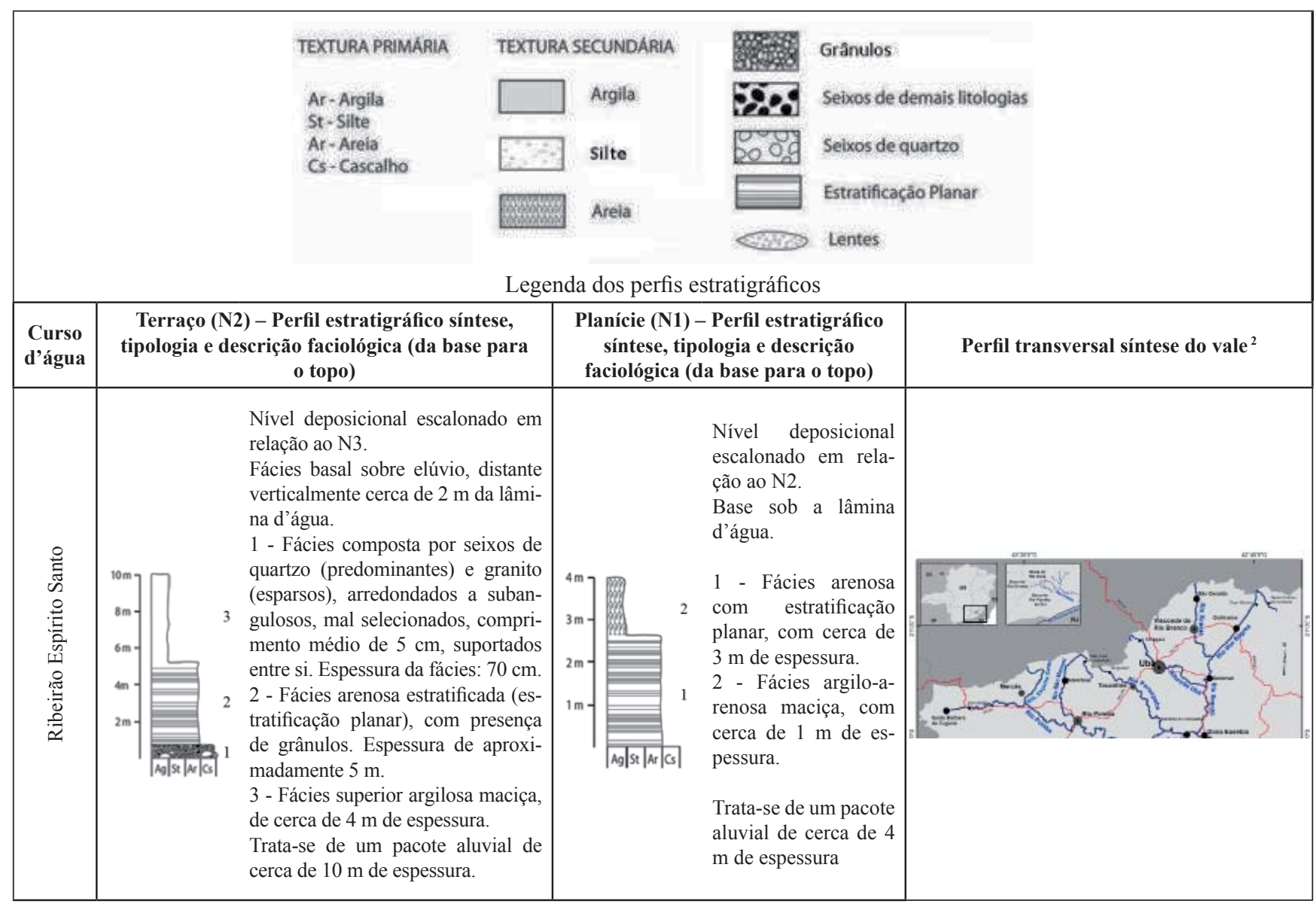

${ }^{2}$ Por tratar-se do perfil transversal síntese do vale, os níveis deposicionais mais antigos (N3 e N4), que não pertencem mais ao contexto de fundo de vale mas sim ao contexto de vertente, foram, também, representados. A exibição desses níveis no perfil transversal se justifica, ainda, por possibilitar a compreensão da tipologia dos depósitos de N2: sempre escalonados em relação ao N3. 


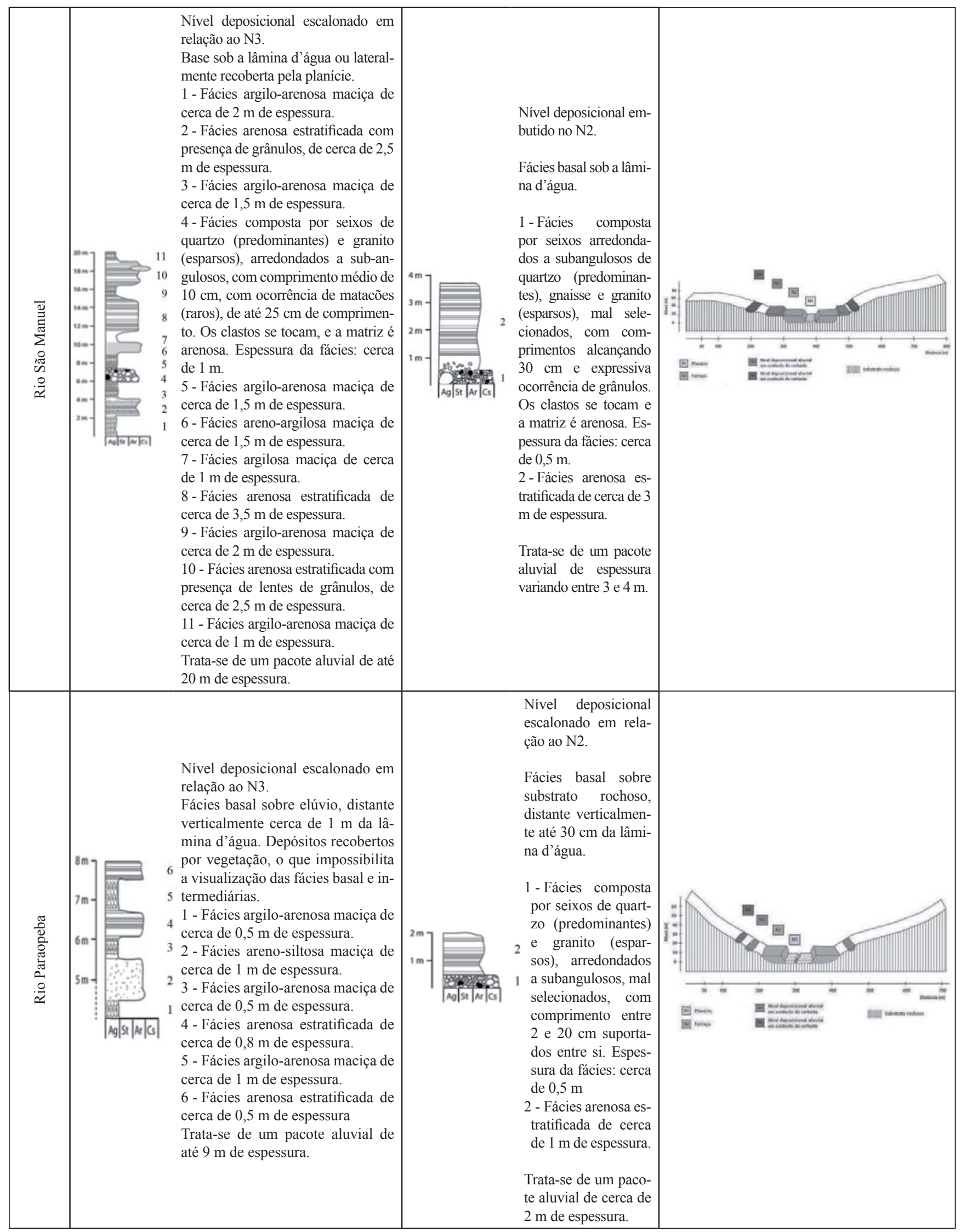




\begin{tabular}{|c|c|c|c|c|c|c|}
\hline 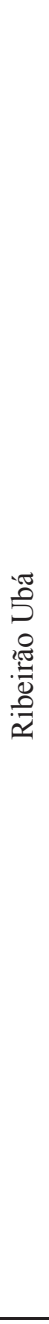 & (1) & $\begin{array}{l}\text { Nível deposicional escalonado } \\
\text { em relação ao N3. } \\
\text { Base sob a lâmina d'água. } \\
1 \text { - Fácies argilosa maciça de } \\
\text { cerca de } 1 \mathrm{~m} \text { de espessura. } \\
2 \text { - Fácies arenosa estratificada } \\
\text { com ocorrência de grânulos e } \\
\text { pequenos seixos (até } 2 \mathrm{~cm} \text { de } \\
\text { comprimento). Espessura da } \\
\text { fácies: cerca de } 2 \mathrm{~m} \text {. } \\
3 \text { - Fácies argilosa maciça de } \\
\text { cerca de } 1,3 \text { m de espessura. } \\
4 \text { - Fácies arenosa estratifica- } \\
\text { da com ocorrência de lentes } \\
\text { de grânulos e pequenos seixos } \\
\text { (até } 3 \text { cm de comprimento). } \\
\text { Espessura da fácies: cerca de } \\
1,5 \text { m. } \\
5 \text { - Fácies argilo-arenosa ma- } \\
\text { ciça de cerca de } 2,5 \text { m de es- } \\
\text { pessura. } \\
6 \text { - Fácies arenosa estratificada } \\
\text { de cerca de } 1,5 \mathrm{~m} \text { de espessura } \\
\text { Trata-se de um pacote aluvial } \\
\text { de cerca de } 10 \text { m de espessura. }\end{array}$ & im 1 & $\begin{array}{l}\text { Nível deposicional } \\
\text { embutido no N2. } \\
\text { Base sob a lâmina } \\
\text { d'água. } \\
1 \text { - Fácies basal } \\
\text { composta por sei- } \\
\text { xos e grânulos de } \\
\text { quartzo e rochas } \\
\text { ígneas máficas, } \\
\text { subarredondados a } \\
\text { angulosos, supor- } \\
\text { tados por matriz } \\
\text { arenosa. Os seixos } \\
\text { possuem compri- } \\
\text { mento médio de } \\
3 \text { cm. Espessura } \\
\text { da fácies: cerca de } \\
0,5 \text { m. } \\
2 \text { - Fácies arenosa } \\
\text { estratificada, com } \\
\text { a presença de len- } \\
\text { tes de grânulos e } \\
\text { pequenos seixos } \\
\text { de quartzo (predo- } \\
\text { minantes) e rochas } \\
\text { ígneas máficas } \\
\text { (esparsos). Espes- } \\
\text { sura da fácies: cer- } \\
\text { ca de } 1,5 \text { m. } \\
\text { Trata-se de um } \\
\text { pacote aluvial de } \\
\text { cerca de } 2 \text { m de } \\
\text { espessura. }\end{array}$ & 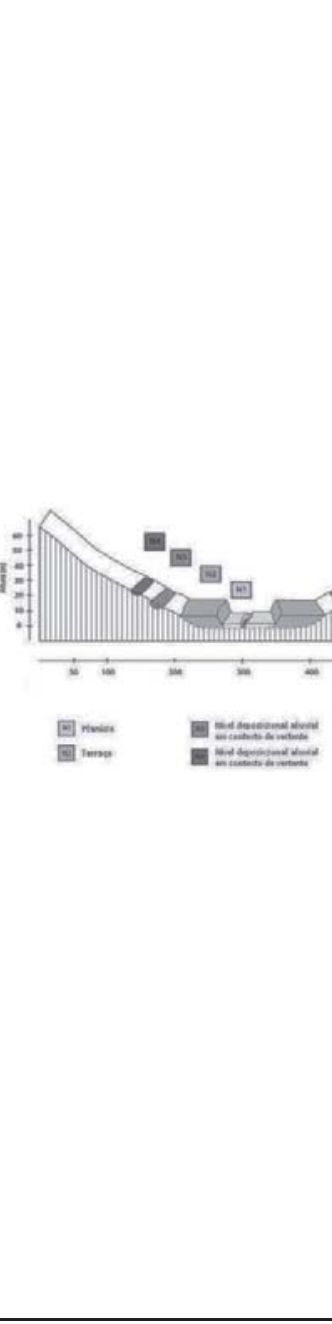 & ت \\
\hline 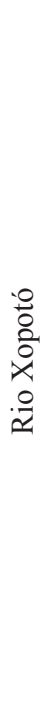 & 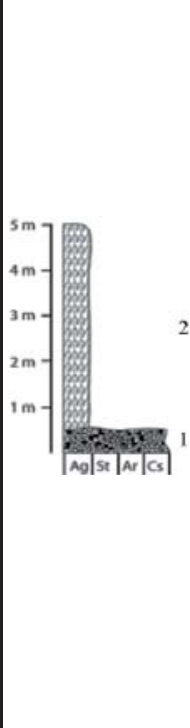 & $\begin{array}{l}\text { Nível deposicional escalonado } \\
\text { em relação ao N3. } \\
\text { Fácies basal sobre rocha, } \\
\text { distante verticalmente cerca de } \\
1,5 \text { m da lâmina d'água. } \\
1 \text { - Fácies composta por grânulos } \\
\text { e pequenos seixos de quartzo, } \\
\text { granito e gnaisse (comprimen- } \\
\text { to médio de } 2 \mathrm{~cm} \text { ), angulosos a } \\
\text { subarredondados e suportados } \\
\text { entre si, embora haja abundân- } \\
\text { cia de matriz arenosa. Espes- } \\
\text { sura da fácies: } 0,5 \text { m. } \\
2 \text { - Fácies argilo-arenosa maciça, } \\
\text { de cerca de } 4,5 \text { m de espessura. } \\
\text { Trata-se de um pacote aluvial } \\
\text { de cerca de } 5 \text { m de espessura. }\end{array}$ & $\underbrace{2 \mathrm{~m}-1}$ & $\begin{array}{l}\text { Nível deposicional } \\
\text { escalonado em } \\
\text { relação ao N2. } \\
\text { Base sob a lâmina } \\
\text { d'água. } \\
1 \text { - Fácies areno-ar- } \\
\text { gilosa, ora maciça, } \\
\text { ora com presença } \\
\text { de estratificação. } \\
\text { Espessura da fá- } \\
\text { cies: cerca de } 3 \text { m. } \\
\text { Trata-se de um } \\
\text { pacote aluvial de } \\
\text { cerca de } 3 \text { m de } \\
\text { espessura. }\end{array}$ & 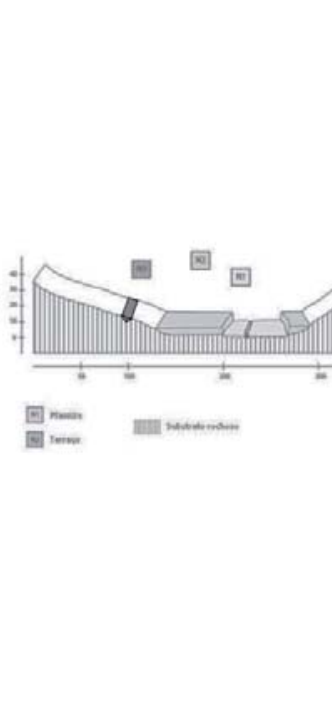 & 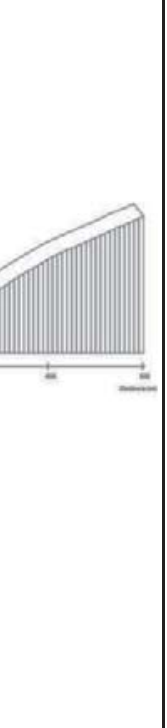 \\
\hline
\end{tabular}




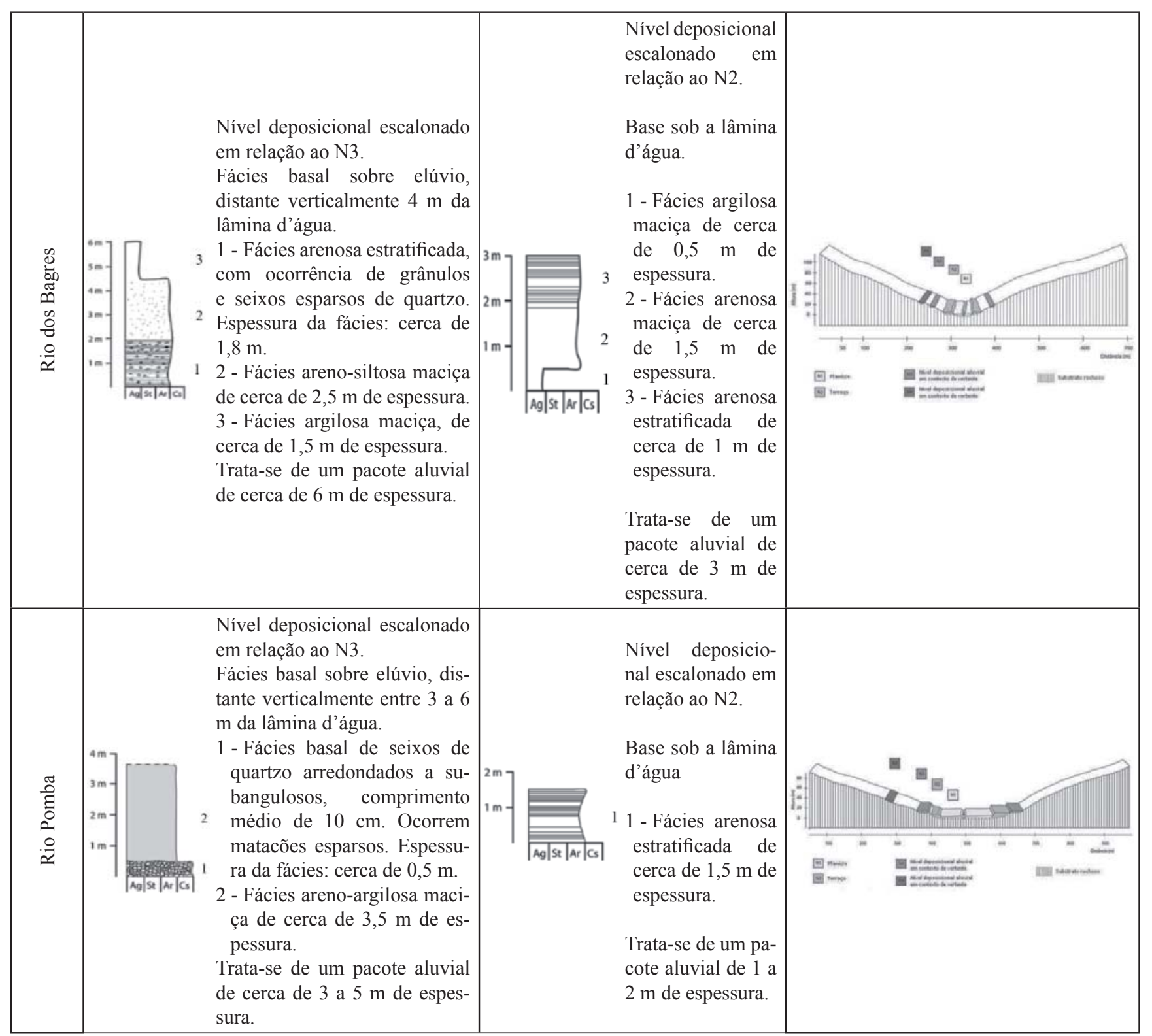

Figura 4 - Descrição síntese dos depósitos fluviais de terraço e planície por vale estudado

As figuras 6 e 7 apresentam os resultados da datação via LOE - protocolo SAR dos sedimentos fluviais da área. A amostra 3 apresenta-se como a mais relevante do ponto de vista das interpretações deste trabalho, uma vez que baliza a taxa de encaixamento do alto curso do Ribeirão Ubá, bem como o início do processo de entulhamento que resultou nos espessos depósitos fluviais. As idades obtidas para as planícies variam entre 1.500 $( \pm 250)$ e 6.000 ( \pm 750$)$ anos, durante os quais não houve encaixamento do canal no trecho próximo ao ponto de coleta, ou o encaixamento foi igual ou inferior a $1 \mathrm{~m}$. A idade de $16.000( \pm 1.500)$ obtida para a planície do alto curso do Rio São Manuel diverge muito das demais, obtidas para planícies morfologicamente semelhantes. Motivos possíveis para essa divergência entre a idade da planície do Rio São Manuel e as demais planícies datadas serão apresentados adiante.

O controle estrutural de alguns segmentos fluviais é evidenciado pelos padrões retilíneos, inclusive com alternância de poços e corredeiras. Exemplos ilustrativos deste controle ocorrem no padrão de drenagem de trechos do Alto Rio Pomba e do Médio-Baixo Rio dos Bagres. As corredeiras correspondem a pequenas irregularidades na calha, que geram convexidades no perfil longitudinal dos canais por vezes pequenas, da ordem de 1 a 2 m. (Figura 8). Porém, sequências de corredeiras 

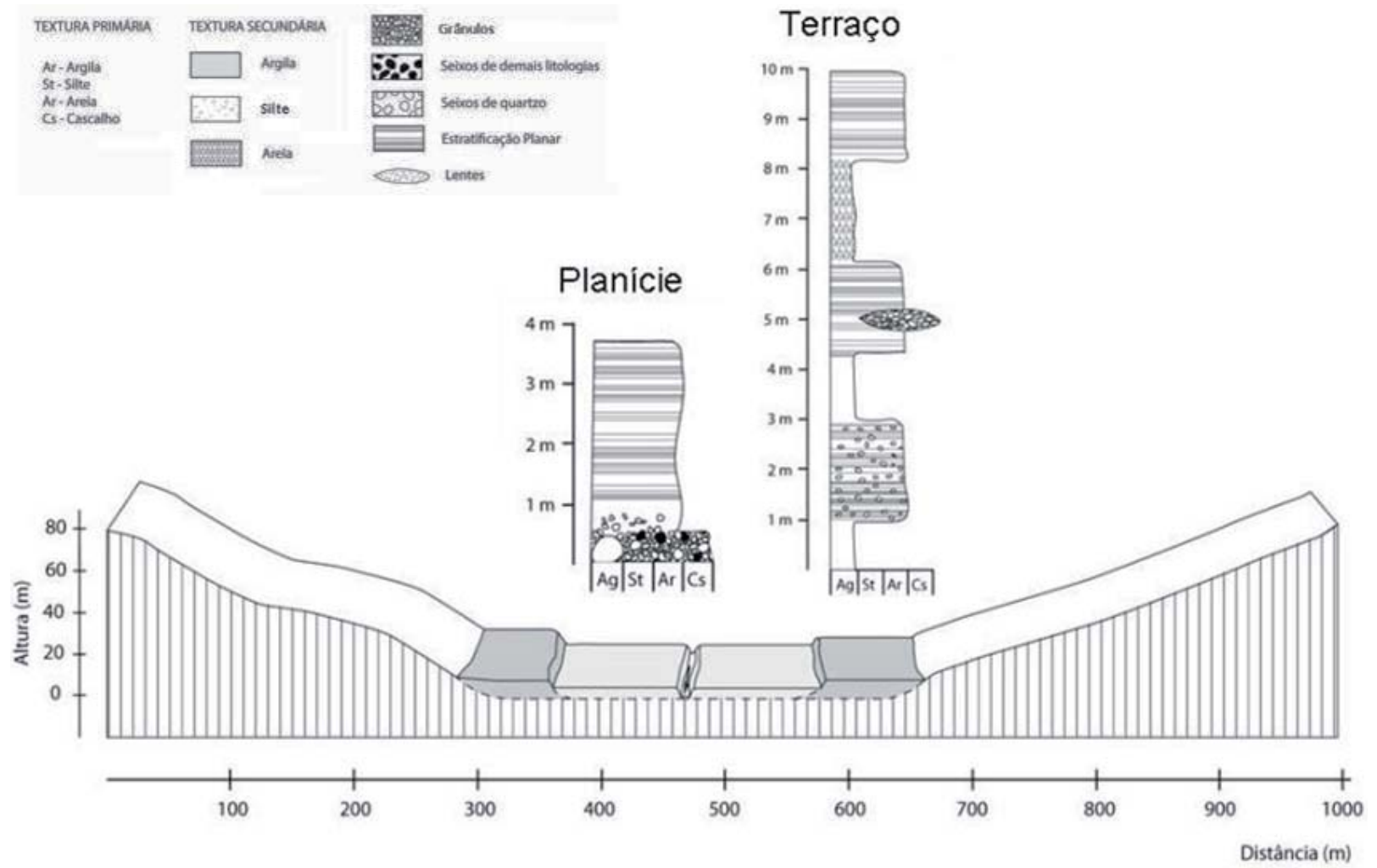

Figura 5 - Síntese da distribuição espacial transversal dos níveis deposicionais de fundos de vale e dos perfis estratigráficos dos terraços e planícies

\begin{tabular}{|c|c|c|c|c|c|c|c|c|c|c|}
\hline Amostra & Vale & Depósito & Th & $\mathbf{U}$ & $\mathbf{K}$ & $\begin{array}{c}\text { Dose } \\
\text { Anual }\end{array}$ & $\begin{array}{c}\text { Dose } \\
\text { Acumulada }\end{array}$ & Idade & $\begin{array}{c}\text { Desnível do } \\
\text { ponto de } \\
\text { coletap ara } \\
\text { o rio atual }\end{array}$ & $\begin{array}{l}\text { Desnivel } \\
\text { da b ase do } \\
\text { nível para } \\
\text { o rio atual }\end{array}$ \\
\hline & & & (ppm) & (ppm) & $(\%)$ & $\begin{array}{c}(\boldsymbol{\mu G} \mathbf{G} / \mathbf{a n} \\
\mathbf{0})\end{array}$ & (Gy) & (anos) & (m) & (m) \\
\hline 1 & $\begin{array}{l}\text { Rio São } \\
\text { Manuel }\end{array}$ & Planície & $\begin{array}{c}13,317 \pm \\
0,479\end{array}$ & $\begin{array}{c}4,202 \pm \\
0,087\end{array}$ & $\begin{array}{c}1,400 \pm \\
0,203\end{array}$ & $\begin{array}{c}3.750 \pm \\
200\end{array}$ & 61 & $\begin{array}{c}16.000 \pm \\
1.500\end{array}$ & 2,5 & 1,5 \\
\hline 2 & $\begin{array}{l}\text { Rio São } \\
\text { Manuel }\end{array}$ & Planície & $\begin{array}{c}14,144 \pm \\
0,509\end{array}$ & $\begin{array}{c}5,193 \pm \\
0,869\end{array}$ & $\begin{array}{c}0,067 \pm \\
0,010\end{array}$ & $\begin{array}{c}2.700 \pm \\
270\end{array}$ & 13,3 & $4.900 \pm 550$ & 1,2 & nenhum \\
\hline 3 & $\begin{array}{c}\text { Ribeirão } \\
\text { Ubá }\end{array}$ & Terraço & $\begin{array}{c}8,334 \pm \\
0,300\end{array}$ & $\begin{array}{c}2,581 \pm \\
0,151\end{array}$ & $0 \pm 0$ & $1.550 \pm 60$ & 18,3 & $\begin{array}{c}11.800 \pm \\
1.000\end{array}$ & 5 & 4 \\
\hline 4 & $\begin{array}{c}\text { Ribeirão } \\
\text { Ubá }\end{array}$ & Planície & $\begin{array}{c}9,341 \pm \\
0,336\end{array}$ & $\begin{array}{c}2,936 \pm \\
0,671\end{array}$ & $\begin{array}{c}0,444 \pm \\
0,064\end{array}$ & $\begin{array}{c}2.200 \pm \\
250\end{array}$ & 3,3 & $1.500 \pm 250$ & 0,7 & nenhum \\
\hline 5 & $\begin{array}{l}\text { Ribeirão } \\
\text { Ubá }\end{array}$ & Planície & $\begin{array}{c}14,716 \pm \\
0,530\end{array}$ & $\begin{array}{c}3,157 \pm \\
1,054\end{array}$ & $\begin{array}{c}0,236 \pm \\
0,034\end{array}$ & $\begin{array}{c}2.400 \pm \\
300\end{array}$ & 15 & $6.000 \pm 750$ & 1 & 1 \\
\hline 6 & $\begin{array}{l}\text { Rio dos } \\
\text { Bagres }\end{array}$ & Planície & $\begin{array}{c}16,375 \pm \\
0,589\end{array}$ & $\begin{array}{c}8,288 \pm \\
1,304\end{array}$ & $\begin{array}{c}0,444 \pm \\
0,064\end{array}$ & $\begin{array}{c}4.000 \pm \\
450\end{array}$ & 6,8 & $1.700 \pm 200$ & 0,8 & 0,5 \\
\hline 7 & $\begin{array}{l}\text { Rio dos } \\
\text { Bagres }\end{array}$ & Planície & $\begin{array}{c}6,328 \pm \\
0,228\end{array}$ & $\begin{array}{c}2,093 \pm \\
0,925\end{array}$ & $\begin{array}{c}0,148 \pm \\
0,021\end{array}$ & $\begin{array}{c}1.400 \pm \\
100\end{array}$ & 4,3 & $3.000 \pm 500$ & 0,7 & nenhum \\
\hline
\end{tabular}

Figura 6 - Síntese das informações sobre os pontos de coleta de amostras para a datação via LOE e resultados obtidos 


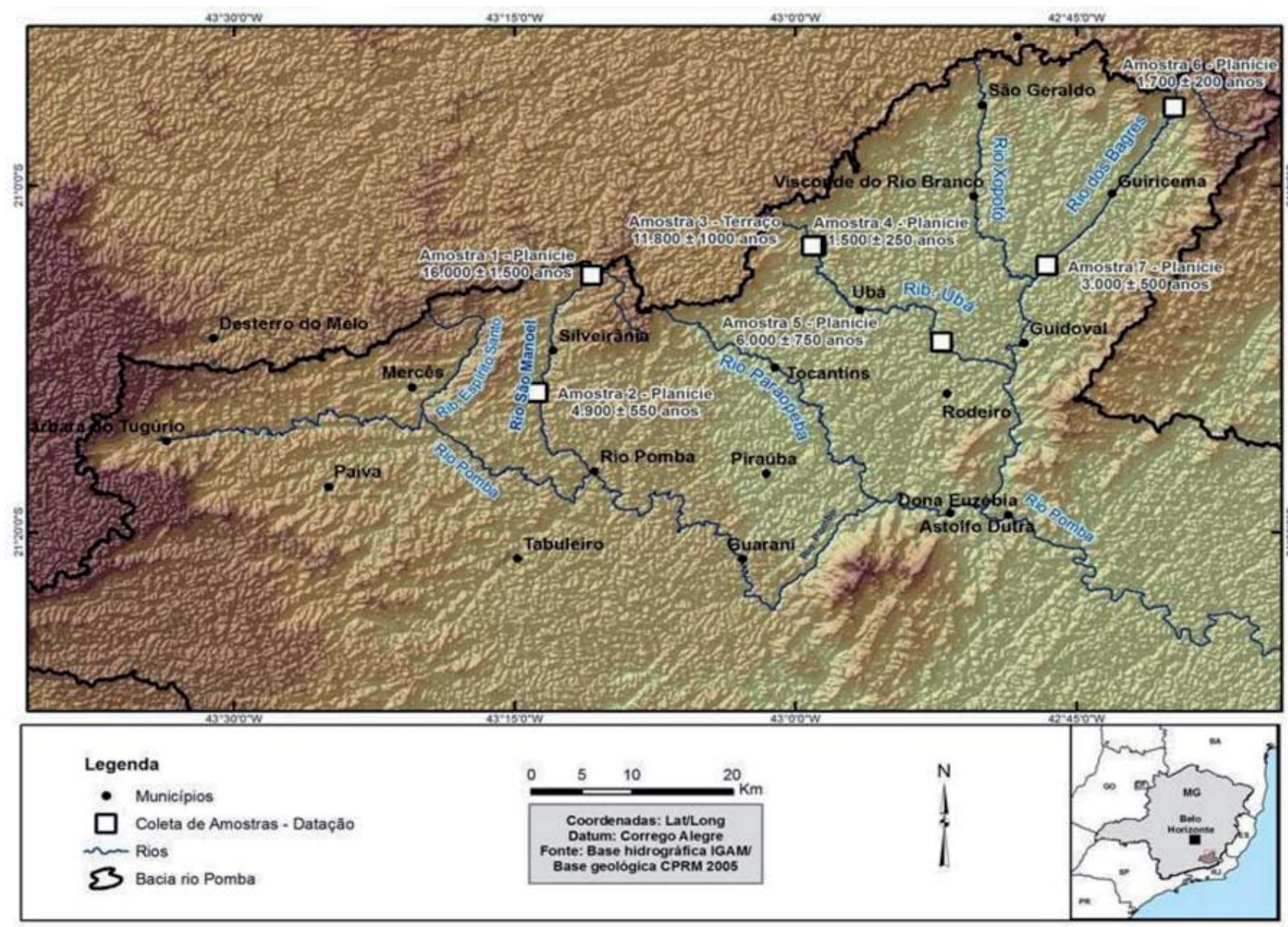

Figura 7 - Localização dos pontos de coleta de amostras para a datação via LOE e resultados obtidos

em calhas rochosas, com fluxos de alta energia e caráter erosivo, também ocorrem no baixo curso do Rio Xopotó e no médio curso do Rio Pomba, nos trechos desses vales nos quais os canais atravessam o Horst da Serra da Boa Vista. Em situações menos frequentes, as corredeiras também ocorrem em calhas aluviais detríticas (seixos e matacões). Como visualizado em campo, nas calhas rochosas, as corredeiras ocorrem em diferentes litologias (não necessariamente nas mais resistentes) e a maior parte não está associada às estruturas geológicas mapeadas, podendo ocorrer, inclusive, paralelamente (Rio Pomba à montante de Astolfo Dutra), perpendicularmente (Rio Pomba à jusante de Astolfo Dutra) ou obliquamente (segmento do Rio Xopotó) à direção principal das estruturas (NE-SW). No restante da área, as corredeiras são raras, sobretudo nos médios e baixos cursos dos rios Paraopeba e Xopotó e do Ribeirão Ubá. A figura 9 traz a localização dos trechos da calha em corredeira, bem como a espacialização dos terraços e planícies nos fundos de vale, associada à compartimentação regional do relevo.

\section{Discussão dos Resultados}

Considerações sobre os eventos de entulhamento dos fundos de vale e os indícios de condicionamento tectônico da dinâmica fluvial regional

A área estudada é marcada por vales abertos e de fundo plano, predominantemente preenchidos por espessos terraços que podem atingir mais de $10 \mathrm{~m}$ de espessura, ou, nos baixos cursos dos canais, por amplas planícies com até $500 \mathrm{~m}$ de largura.

O nível de terraço (N2) apresenta evidências de uma gênese a partir de processos de acresção lateral e vertical, denotando intenso entulhamento do fundo de vale. Um dos elementos mais ilustrativos deste processo de entulhamento é a existência recorrente, nos mesmos perfis, de fácies de seixos sobrepostas a fácies de finos e intercaladas a estas, evidenciando a elevação da calha à medida que o canal migrava lateralmente no fundo do vale. Os eventos de agradação responsáveis pela origem do nível de terraço têm suas idades balizadas pela data- 


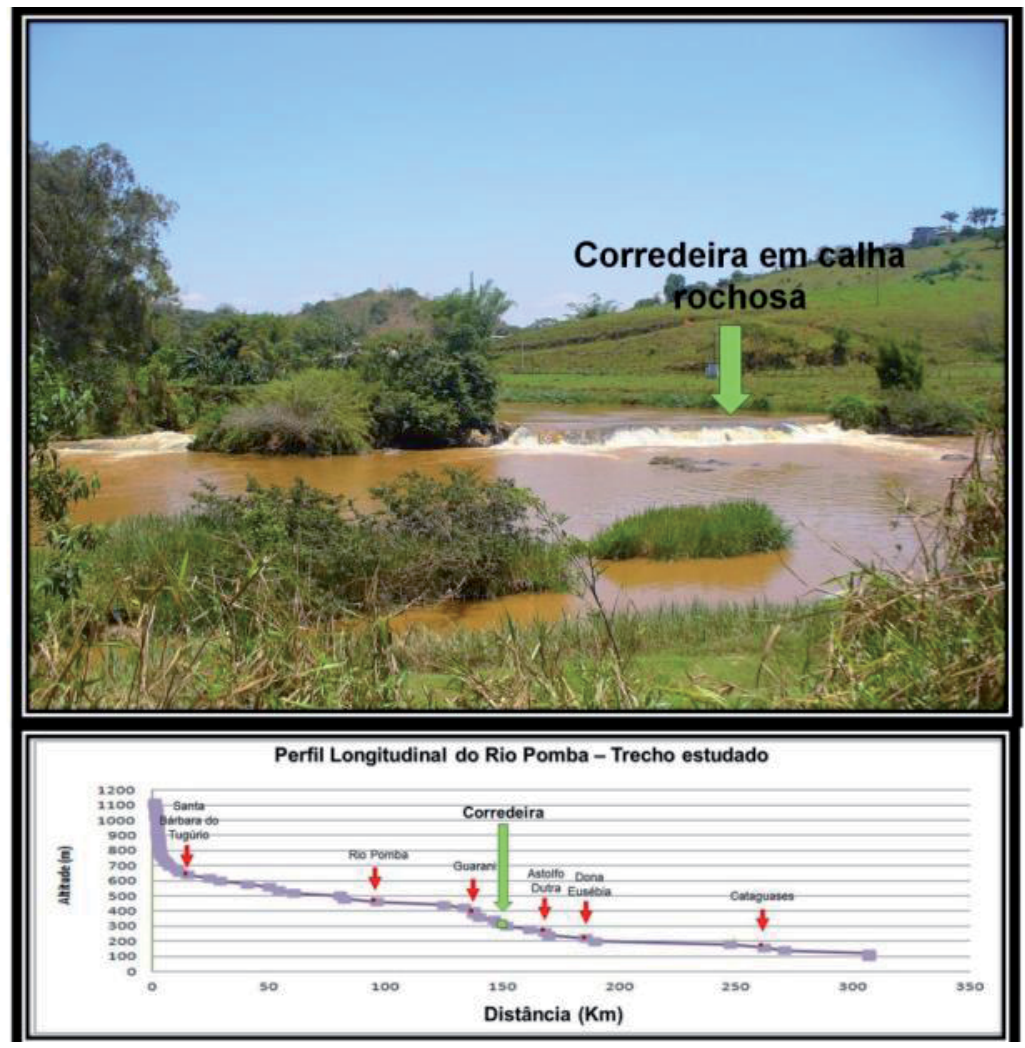

Figura 8 - Corredeira no médio Rio Pomba

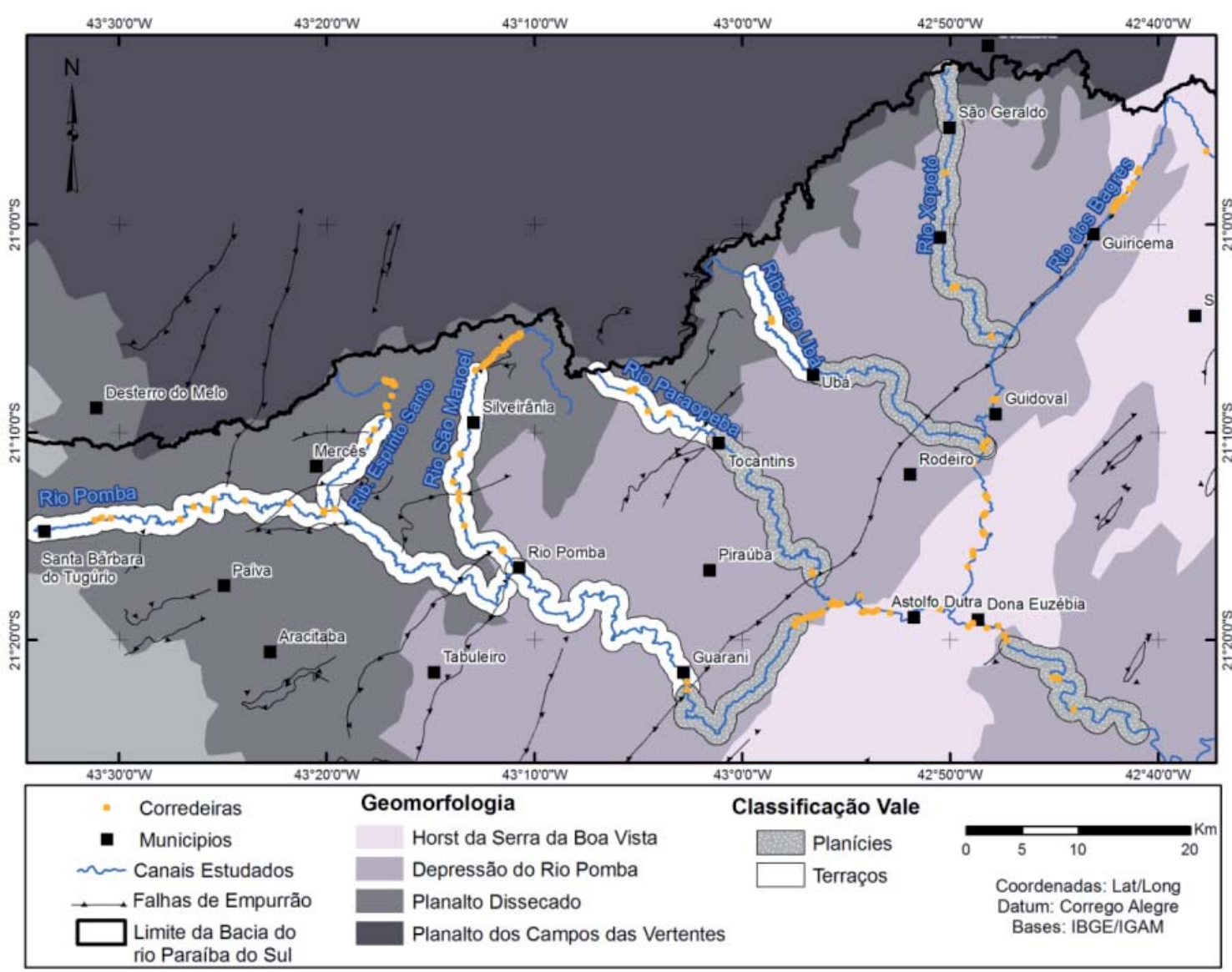

Figura 9 - Distribuição dos depósitos aluviais de fundo de vale e dos trechos de calha em corredeira nas principais unidades regionais do relevo. 
ção dos sedimentos do terraço do Ribeirão Ubá (amostra $3)$, a saber, de $11.800( \pm 1.000)$ anos. Essa idade coincide com a transição climática ocorrida entre o Pleistoceno e o Holoceno. Porém, apesar de vários trabalhos apontarem a influência climática nos processos de erosão e entulhamento dos fundos de vale neste período (Meis \& Moura, 1984; Moura et al., 1991; Queiroz Neto, 2001; Liccardo et al., 2003; Missura \& Corrêa, 2007; Paisani et al., 2012; Xavier \& Coelho Netto, 2014), a própria organização estratigráfica das fácies dos perfis descritos não indica uma gênese associada a mudanças climáticas, nem relacionada às condições de vazão atuais dos cursos d'água. Nos atuais regimes fluviais, os fluxos não são capazes de gerar pacotes sedimentares tão espessos porque, ainda que as condições climáticas atuais estejam dentre as mais úmidas do Holoceno (Barros et al., 2011), mesmo durante eventos de inundação, os canais não conseguem recobrir depósitos cujos topos distam $10 \mathrm{~m}$ da lâmina d'água. Para tal, é necessário que haja uma suspensão da calha, resultante do entulhamento do canal. Esse processo é denotado, nos perfis de terraço, pela alternância entre fácies geradas tipicamente por acresção lateral e as geradas por acresção vertical.

Em busca de explicações para os eventos de suspensão das calhas e entulhamento dos fundos de vales, pode-se partir das possibilidades de atuação pretérita de soleiras litológicas, apesar da não existência de bases cartográficas que comprovem a difusão de diques ou outras faixas de litologias mais resistentes em meio às maiores unidades. Nessa hipótese, soleiras na calha do baixo Rio Pomba poderiam ter propagado seus efeitos ao longo das calhas dos tributários. Entretanto, neste segmento, o fundo de vale do Rio Pomba não se apresenta colmatado como os de seus afluentes, sugerindo que o barramento teria se estabelecido no Médio Rio Pomba ou mesmo nos vales dos próprios tributários. Porém, na busca de explicações para a colmatação dos fundos de vales, fatores locais como soleiras litológicas dificilmente ocasionariam a formação sincronizada de pacotes sedimentares estratigraficamente semelhantes e com espessuras superiores a $10 \mathrm{~m}$. A explicação a partir dos aspectos tectono-estruturais torna-se mais consistente, já que trata-se de uma região diretamente afetada pelo dinamismo tectônico da faixa atlântica brasileira no Cenozoico.

A análise da distribuição espacial dos elementos fluviais descritos permite inferir que as movimentações tectônicas, possivelmente próximas ao contato entre os complexos Mantiqueira e Juiz de Fora, podem ter gerado o barramento dos eixos de drenagem, embora não necessariamente por meio de reativação da falha de empurrão que estabelece o contato entre essas unidades geológicas. A ocorrência de movimentações tectônicas recentes no Horst da Serra da Boa Vista foi proposta por Noce et al. (2003) e pode estar evidenciada pela morfologia dos vales (estreitos, com características de vale em "V"), pela ausência de depósitos aluviais e pela concentração de corredeiras em calhas rochosas nos trechos dos vales que drenam o horst.

A ascensão do Horst da Serra da Boa Vista não parece ter se iniciado no Holoceno, uma vez que, se o início fosse recente e precedido de uma quiescência desse bloco em relação aos limítrofes, os rios Xopotó e Pomba tenderiam a expandir os fundos de vale e gerar planícies amplas, como ocorre nos demais vales estudados e em outros segmentos desses próprios vales. Uma movimentação tectônica iniciada no Holoceno também resultaria em depósitos aluviais abandonados ainda preservados, possivelmente como terraços. Isso não se observa: os vales dos rios Xopotó e Pomba, na passagem epigênica pelo Horst da Serra da Boa Vista, são estreitos, com planícies pouco desenvolvidas e total ausência de registros de terraços ou de níveis deposicionais mais antigos já descaracterizados morfologicamente e incorporados ao contexto de vertente. Cabe ressaltar que o padrão morfológico dos cursos d'água na passagem pelo horst não é retilíneo e não há evidências cartográficas da existência de lineamentos antigos controlando a abertura do corte epigênico.

A morfologia dos vales sugere, portanto, que nos trechos citados, os períodos erosivos predominariam há mais tempo e estariam associados à movimentação do horst (ainda que não contínua) e não à propagação de eventos erosivos iniciados à jusante (no vale do Rio Paraíba do Sul, por exemplo). Corrobora para tal hipótese o fato do Rio Pomba em seu baixo curso (à jusante do horst) ter vale aberto com planície e terraço amplos, não denotando constante submissão a eventos erosivos.

Essas movimentações tectônicas seriam as responsáveis pelo represamento da drenagem, que culminou no entulhamento dos fundos de vale em toda a bacia do alto-médio Rio Pomba. Conforme a datação da base do depósito de terraço no alto curso do Ribeirão Ubá, o evento de colmatação iniciou-se, no alto curso dos afluentes do Rio Pomba, há cerca de 11.800 anos. Conforme Hartwig e Riccomini (2009), a Serra dos 
Órgãos no estado do Rio de Janeiro esteve sob compressão holocênica de direção E-W. Portanto, a área de estudo pode ter sofrido influência destes movimentos, sofrendo a reativação de lineamentos transcorrentes de regime dextral e direção E-W durante o Holoceno, com ascensão de blocos responsáveis pelo represamento da drenagem. Segundo Salvador e Riccomini (1995), as mudanças no regime de esforços durante o Holoceno (passando estes a extensionais, com direção WNW-ESE) foram responsáveis pela geração de feições marcantes no relevo do Alto Estrutural de Queluz, nos estados de São Paulo e Rio de Janeiro, com formação de pacotes sedimentares com espessuras superiores a 30 m, em grabens de direção N-S.

A concentração de corredeiras nos segmentos fluviais dos rios Xopotó e Pomba que drenam o horst sugerem uma continuidade das movimentações tectônicas durante o Holoceno. Considerando-se que a alternância de poços e corredeiras é mais frequente nos altos cursos fluviais (Montgomery e Buffington, 1997), onde o gradiente é maior e os canais transportam carga de leito mais grosseira (portanto, com maior capacidade de abrasão), a concentração de corredeiras em leitos rochosos nos baixos cursos dos rios Xopotó e Pomba apresenta-se como relativamente anômala. Diante do regime fluvial e do poder erosivo dos fluxos nesses trechos, seria de se esperar que já houvesse ocorrido a regularização das calhas caso houvesse uma estabilidade tectônica local no Holoceno. O alto curso do Ribeirão Ubá, com vazão consideravelmente menor que a dos rios Pomba e Xopotó (embora com maior gradiente), encaixou cerca de $4 \mathrm{~m}$ durante os últimos 11.800 anos $( \pm 1.000)$, conforme idade obtida para a amostra 3, correspondente ao terraço do Ribeirão Ubá (Figura 9). Não é simples, portanto, supor que os baixos cursos dos canais principais da área não conseguiriam atingir o pequeno encaixamento necessário para a eliminação das corredeiras no mesmo intervalo de tempo. A manutenção da irregularidade das calhas parece, portanto, ter motivação tectônica bastante recente.

Atualmente, a dinâmica erosiva parece ter sido freada por níveis de base locais representados por quedas d'água ou trechos encachoeirados no médio-baixo Rio Xopotó e no baixo Rio Paraopeba, que estabelecem o contato do horst com os blocos adjacentes à montante e estão associados a contatos litológicos. A estabilização do nível de base vem permitindo a esses cursos d'água e ao Ribeirão Ubá intenso meandramento, por meio do qual os canais erodem depósitos aluviais abandonados e formam amplas e espessas planícies. As idades obtidas para os depósitos de planície indicam uma propagação remontante do evento deposicional ao qual a formação das planícies está associada, na medida em que as dos baixos cursos são mais velhas que as dos altos cursos (Ribeirão Ubá: a planície do alto curso tem 1.500 ( \pm 250) anos, já a planície do baixo curso tem $6.000( \pm$ 750) anos; Rio dos Bagres: a planície do alto curso tem $1.700( \pm 200)$ anos, já a planície do baixo curso tem 3.000 ( \pm 500$)$ anos). A exceção seria o Rio São Manuel, no qual a planície do alto curso apresentou idade bastante superior à das demais planícies $(16.000$ \pm 1.500 anos), incluindo a planície de baixo curso do mesmo canal, que apresentou idade de 4.900 ( \pm 550) anos. Não havendo indícios geomorfológicos que indiquem um comportamento diferenciado do Rio São Manuel que justifique a formação de sua planície no alto curso anteriormente à formação da planície no baixo curso e anteriormente, ainda, à formação do nível de terraço (o qual, no Ribeirão Ubá, apresenta a idade de $11.800 \pm 1.000$ anos), é possível que tenha ocorrido superestimação da idade da amostra datada (amostra 1). O depósito no qual foi realizada a coleta está situado bastante próximo da escarpa da Serra da Mantiqueira, o que pode ocasionar o zeramento parcial da luminescência dos grãos de quartzo anteriormente à deposição, uma vez que o transporte dos mesmos pelo curso d'água teria ocorrido por pequena distância. $\mathrm{O}$ zeramento parcial da luminescência, decorrente da exposição insuficiente à luz solar durante o transporte fluvial, teria ocasionado a superestimação da idade da amostra dessa planície do Rio São Manuel. É possível que, tendo ocorrido o zeramento parcial de todos os grãos de quartzo da amostra (ou da maior parte deles), nem mesmo o protocolo SAR tenha possibilitado a identificação desse problema, mesmo sabendo-se que foi realizada a leitura do sinal luminescente dos grãos de quartzo individualmente.

Observa-se, ainda, que houve pequeno ou nenhum encaixamento da drenagem após o início da formação das planícies, indicando um longo período de estabilização do nível de base, durante o qual os canais predominantemente meandraram, destruindo depósitos aluviais mais antigos. Duarte et. al. (2010) verificaram que a morfologia das planícies do Rio Pomba e de seus afluentes deve estar associada a evento de intenso entulhamento dos fundos de vale, processo resultante do 
aporte sedimentar excessivo oriundo da desestabilização das vertentes. Embora atualmente a contribuição antrópica para o elevado fornecimento sedimentar às calhas fluviais seja inegável na Zona da Mata mineira (onde o uso do solo inadequado potencializa a susceptibilidade natural aos voçorocamentos, por exemplo), os sedimentos fornecidos influenciam fortemente o aumento da espessura das planícies: já a amplitude das mesmas nos vales dos rios Paraopeba e Xopotó e do Ribeirão Ubá exige outro viés de explicação. Os amplos fundos de vale são mais facilmente correlacionáveis a estágios de estabilidade do nível de base, os quais permitiriam uma dinâmica de meandramento e migração lateral dos canais. Tal dinâmica fica evidenciada pela recorrência de meandros abandonados e pelo fato dos depósitos de terraços terem sido removidos nos médios-baixos Ribeirão Ubá e Rio Paraopeba. O arrasamento dos fundos de vale promovido por este intenso processo de migração lateral dos canais tende a avançar em direção à montante, à medida que os perfis longitudinais dos canais forem sendo regularizados. Como consequência, a área de ocorrência dos espessos depósitos de terraço tende e limitar-se cada vez mais à alta bacia do Rio Pomba, na qual as características morfológicas do Planalto Dissecado da Bacia do Rio Pomba minimizam a atuação de um nível de base local bem marcado.

\section{Conclusões}

A reconhecida atividade neotectônica da borda leste brasileira parece influenciar a organização espacial da drenagem e a individualização de domínios morfológicos na região. A geomorfologia da área de estudos parece refletir uma dinâmica de pulsos temporais e períodos de estabilidade de estruturas mais localizadas, como o Horst da Serra da Boa Vista, além das possíveis influências da ativação de macroestruturas regionais, como o Sistema de Rifts da Serra do Mar e os grabens associados. A colmatação dos fundos de vale, a disposição dos trechos de calha rochosa com corredeiras, a amplitude das planícies nos baixos cursos dos canais que drenam a Depressão do Rio Pomba e a morfologia dos vales no horst sugerem uma dinâmica de pulsos de ascensão do Horst da Serra da Boa Vista, decisiva na configuração dos eventos erosivos e deposicionais ocorridos à montante.

Uma ascensão do horst há cerca de 11.800 anos teria provocado a colmatação dos vales à montante, uma vez que teria represado a drenagem e provocado o intenso entulhamento dos fundos de vale e a elevação das calhas. Esse entulhamento culminou em espessos depósitos aluviais cuja gênese está associada a processos de acresção tanto lateral quanto vertical. Diante da posterior estabilização do horst, a rede de drenagem, submetida ao soerguimento contínuo do Escudo Brasileiro, passou a encaixar nos sedimentos e atualmente há pequenos trechos de calhas rochosas em diversas porções de todos os vales. Após o encaixamento, as marcantes quedas d'água configuradas no contato entre o horst e os blocos adjacentes à montante passaram a atuar como níveis de base que controlam a dinâmica fluvial, freando os processos de encaixamento, mesmo em uma área sob epirogênese positiva. A redução da energia dos fluxos levou à migração lateral dos canais, sobretudo daqueles que drenam a Depressão do Rio Pomba. O intenso meandramento abriu os fundos de vale e destruiu depósitos aluviais mais antigos: este seria o motivo pelo qual, nos baixos cursos do Ribeirão Ubá e dos Rios Paraopeba e Xopotó, o fundo de vale é composto apenas por planícies amplas nas quais meandros abandonados são abundantes.

No contexto de evolução e abertura da Depressão do Rio Pomba, a ampliação lateral dos fundos de vale tem migrado em direção aos segmentos fluviais superiores (altos cursos), em processos de avanço remontante, conforme corroborado pelas datações das planícies de alto e baixo curso do Ribeirão Ubá e do Rio dos Bagres. Até mesmo nos altos cursos, o encaixamento da drenagem nos últimos 1.500 anos foi nulo no Ribeirão Ubá; e de apenas 0,5 m em 1.700 anos no Rio dos Bagres. Estes processos de arrasamento dos fundos de vale provocam a desestabilização das vertentes e, consequentemente, a intensificação de processos de encosta, que ficam evidenciados pela presença de rampas coluviais nas bordas dos fundos de vales, recobrindo os sedimentos aluviais. A abertura e a configuração dos fundos de vales têm reforçado as características morfológicas da Depressão do Rio Pomba, já que têm comandado os processos de suavização do relevo regional.

A datação de sedimentos aluviais via LOE - protocolo SAR auxiliou a formulação de hipóteses sobre a configuração da rede hidrográfica e do relevo regional. Diante da utilização ainda pouco frequente da LOE, é válido ressaltar a importância da utilização do protocolo SAR, de modo a reduzir a possibilidade de superestimação das idades. Sobretudo em áreas nas quais sejam 
comuns processos de vertentes e nos casos de a amostra a ser datada situar-se nas proximidades da área fonte, deve-se optar pelo protocolo SAR, de modo a aumentar as chances de identificação do problema de zeramento parcial da luminescência durante o transporte do grão de quartzo, caso ele ocorra.

\section{Referências Bibliográficas}

ALMEIDA, F. F. M. The system of continental rifts bordering the Santos Basin, Brazil. Anais Acad. Bras. Cienc, (supl.) p. 15-26. 1976.

BARROS, L. F. P.; LAVARINI, C.; LIMA, L. S.; MAGALHÃES JÚNIOR, A. P. Síntese dos cenários paleobioclimáticos do Quaternário tardio em Minas Gerais/Sudeste do Brasil. Uberlândia: Revista Sociedade e Natureza. V 23, n. 3, p. 371386, 2011.

BRANDALISE, L. A.; VIANA, H. S. Programa Levantamentos Geológicos Básicos do Brasil; carta geológica, carta metalogenética/previsional - escala 1:100.000 (Folha Rio Pomba, SF.23-X-D-I) Estado de Minas Gerais. DNPM/ CPRM, 1993.

CORRÊA, A. C. B.; SILVA, D. G. da; MELLO, J. S. Utilização dos depósitos de encostas dos brejos pernambucanos como marcadores paleoclimáticos do Quaternário Tardio no semi-árido nordestino. Mercator, V. 7, p. 99-125, 2008.

DUARTE, M. P.; PARAGUASSU, L.; BARROS, A. C. L.; SAADI, A. Erosão na Zona da Mata mineira: condicionantes naturais e efeitos antrópicos. VIII SINAGEO, Recife, 2010.

FERRARI, A. L. Evolução Tectônica do Graben da Guanabara. 2001. 412 f. Tese (Doutorado) - Instituto de Geociências, Universidade de São Paulo, São Paulo, 2001.

HARTWIG, M. E.; RICCOMINI, C. Padrão de fraturas da região da Serra dos Órgãos (RJ) e sua relação com a tectônica mesozóico-cenozóica do sudeste do Brasil. Revista Brasileira de Geociências, $V$ 39, п. 3: 452-464, 2009.

HIRUMA, S. T.; RICCOMINI, C.; MODENESI-GAUTTIERI, M. C. Neotectônica no planalto de Campos do Jordão, SP. Revista Brasileira de Geociências, V. 31, n. 3, p. 375-384, 2001.

LICCARDO, A.; ADDAD, J. E.; SIMÕES, L. Depósitos secundários quaternários de Coríndon em Minas Gerais. In: IX Congresso da Associação Brasileira de Estudos Quaternários, 9, Recife. II Congresso do Quaternário de Países de Língua Ibérica e II Congresso sobre Planejamento e Gestão da Zona Costeira dos Países de Expressão Portuguesa. Anais do IX Congresso...
Recife : ABEQUA, 2003.

MEIS, M.R.M. \& MOURA, J.R.. Upper Quaternary sedimentations and hillslope evolution. Am. Journal Science. 284:241- 254, 1984.

MELLO, C. L. Sedimentação e Tectônica Cenozóicas no Médio Vale do Rio Doce (MG, Sudeste do Brasil) e suas implicações na evolução de um sistema de lagos. Tese (Doutorado) - Instituto de Geociências, Universidade de São Paulo, São Paulo, 1997, 275p.

MISSURA, R.; CORREA, A. C. B. Evidências Geomorfológicas como Ferramentas para a Reconstrução Paleogeográfica na Mantiqueira Ocidental- MG. Revista de Geografia (Recife), v. 24, p. 262-278, 2007.

MONTGOMERY, D. R.; BUFFINGTON, J. M. Channel-reah Morphology in Mountain Drainage Basins. The Geological Society of America Bulletin, v. 109, n. 5, p. 596-611, 1997.

MOURA, J. R. S.; PEIXOTO, M. N. O.; SILVA, T. M. Geometria do relevo e estratigrafia do quaternário como base à tipologia de cabeceiras de drenagem em anfiteatro - médio vale do Rio Paraíba do sul. Revista Brasileira de Geociências. V. 21, n. 3 , p. 255-265, 1991.

NOCE, C. M.; ROMANO, A. W.; PINHEIRO, C. M.; MOL, V. S.; PEDROSA-SOARES, A. C. Folha SE.X-D-II: Ubá. In: COMIG (Editor), Projeto Leste, Belo Horizonte, 2003.

PAISANI, J. C.; PONTELLI, M. E.; CALEGARI, M. R. Evolução de bacias de baixa ordem nos 41.000 anos AP - Brasil Meridional. Revista Mercator. V. 11, n. 26. 2012.

PROJETO-RADAMBRASI. Folhas SF 23/24 Rio de Janeiro/ Vitória, geologia, geomorfologia, pedologia, vegetação e uso potencial da terra, 32. CPRM, Rio de Janeiro, 780 p, 1983.

QUEIROZ NETO, J. P. O estudo de formações superficiais no Brasil. São Paulo: Revista do Instituto Geológico. V. 22, n. 2, 65-78, 2001.

RAPOSO, A. A.; SALGADO, A. A. R. Mapeamento das unidades do relevo da região dos divisores de águas das bacias hidrográficas dos rios São Francisco/Doce/Paraíba do Sul. In: Semana de Iniciação Científica da UFMG. Belo Horizonte: UFMG, 2010.

RICCOMINI, C. O Rift Continental do Sudeste do Brasil. 1989. 304 f. Tese (Doutorado) - Instituto de Geociências, Universidade de São Paulo, São Paulo, 1989.

RODRIGUES, A. C. A. Análise morfométrica aplicada à investigação da dinâmica diferencial da rede de drenagem 
na Serra da Mantiqueira: estudo comparativo de afluentes das bacias dos rios Paraíba do Sul e Doce, Zona da Mata em Minas Gerais. Trabalho de conclusão de curso. Departamento de Geografia. Universidade Federal de Minas Gerais. 2011.

SAADI, A. Neotectônica da Plataforma Brasileira: esboço e interpretação preliminares. Geonomos. Belo Horizonte, v. 1, n. 1, p. 1-15, 1993.

SALAMUNI, E.; EBERT, H. D.; HASUI, Y. Morfotectônica da bacia sedimentar de Curitiba. Revista Brasileira de Geociências, V. 34, n. 4, p. 469-478, 2004.

SALlUN, A. E. M.; SUGUIO, K.; Depósitos quaternários da região entre Marília e Presidente Prudente (SP). Revista Brasileira de Geociências, V. 36, n. 3, p. 385-395, 2006.

SALLUN, A.E.M.; SUGUIO, K.; TATUMI, S.H.; YEE, M.; SANTOS, J.; BARRETO, A.M.F. Datação absoluta de depósitos quaternários brasileiros por luminescência. Revista Brasileira de Geociências, V. 37, n. 2, p. 401-412, 2007.

SALVADOR, E. D. Análise tectônica do vale do Rio Paraíba do Sul compreendida entre Cruzeiro (SP) e Itatiaia (RJ). 1994. Dissertação (Mestrado) - Instituto de Geociências, Universidade de São Paulo, São Paulo, 1994, 129p.

SALVADOR, E. D.; RICCOMINI, C. Neotectônica da região do alto estrutural de Queluz (SP-RJ, Brasil). Revista Brasileira de Geociências, V. 25, n. 3, p. 151-164, 1995.

SANTOS, M. dos. Serra da Mantiqueira e Planalto do Rio Grande: a Bacia Terciária de Aiuruoca e evolução morfotectônica. Rio Claro. IGCE - Unesp. Tese de Doutoramento. 225p., 2v, 1999.

SARGES, R. R. Morfologia de lagos da região do médio Vale do Rio Doce, Minas Gerais, e a sua relação com a tectônica quaternária. Dissertação (Mestrado) - Depto de Geologia, Instituto de Geociências, Universidade Federal do Rio de Janeiro, Rio de Janeiro, 2002, 188p.

SILVA, T. P.; e LIMEIRA MELLO, C. Reativações Neotectônicas na Zona de Cisalhamento do Rio Paraíba do Sul (Sudeste do Brasil). Revista do Instituto de Geociências. USP, Sér. cient., São Paulo, V. 11, n. 1, p. 95-111, abril 2011.

SUMMERFIELD, M. A. Global Geomorphology. New York, Longman Scientific \& Technical, 1991, 537p.

XAVIER, R. A.; COELHO NETTO, A. L. Caracterização geomorfológica da bacia do Rio Turvo-RJ: Médio Vale do Rio Paraíba do Sul (MVPRS). Revista Brasileira de Geomorfologia. V. 15, n 1. 2014.

WALLINGA, J. Optically stimulated luminescence dating in fluvial deposits: a review. Boreas, V. 31, p. 303-322, 2002. 